\title{
Judicial Federalism and Constitutional Review in the Swiss Judiciary
}

\author{
Pascal Mahon
}

\subsection{INTRODUCTION}

This chapter deals with the Swiss judicial system. Its aim is to succinctly present the judicial system and to highlight its main features, though length constraints limit this overview to the essential characteristics of the system and what makes it unique. The focus is on two elements: the federalized manner in which the judiciary is organized (Sect. 8.2), and the particularities of Swiss constitutional justice (also called constitutional jurisdiction) (Sect. 8.3).

The chapter first describes the organization of the judicial system, which is strongly marked by the federal character of Switzerland (so there is a pronounced judicial federalism). The philosophy of the system at the federal level is presented, and judicial organization of the cantons is briefly described. The chapter then describes the Swiss system of judicial review (control of the constitutionality of the laws and other state acts), a system which is relatively complete and extended, but, at the same time, has a notable exception in international comparison: Switzerland lacks judicial review of federal laws (and international law).

P. Mahon $(\bowtie)$

Faculty of Law, University of Neuchâtel, Neuchâtel, Switzerland e-mail: pascal.mahon@unine.ch

(C) The Author(s) 2019

A. Ladner et al. (eds.), Swiss Public Administration, Governance and Public Management, https://doi.org/10.1007/978-3-319-92381-9_8 


\subsection{Judicial Organization in General: A Pronounced Judicial Federalism}

\subsubsection{Judicial Federalism and 'Reforming the Judiciary'}

Swiss judicial organization remains very marked by federalism. The application of cantonal law naturally lies with the cantonal judicial authorities. Less naturally, the application of federal law is to a great extent also in the hands of the cantonal judicial authorities. This is generally true for nearly all civil law and practically all criminal law (Art. 122 and 123, respectively, of the Swiss Federal Constitution, abbreviated Const.). Hence, divorces are finalized and murderers prosecuted and punished under material federal law (following the Civil or the Penal Code), by cantonal and not federal prosecuting authorities and courts.

This very pronounced judicial federalism differs from other systems, such as the American, in which two complete, but separate, judicial organizations coexist and yet are superimposed. Put simply, US federal courts deal with federal and inter-state matters while state courts deal with cases arising within their respective states. This is not the case in Switzerland, other than in a few rare cases recently introduced in the context of what is called 'the reform of the judiciary', which is discussed later in this chapter.

Since modern Switzerland began, which is to say since the advent of the modern federal state in 1848, each of the cantons has had a complete judicial organization. Today, their mission, in matters of civil and criminal, and to some extent administrative, is to apply federal law in the same manner as the application of cantonal law. In return, the constituent power in 1848 dispensed with creating an entire federal judicial apparatus. It left to the cantonal judicial authorities, as subordinate bodies, the task of guaranteeing the application of federal law. The federal power limited itself for a long time to only establishing a single higher instance, the Federal Supreme Court, which itself was made permanent only in 1874 .

This sharing of organizational and judicial competencies has been somewhat modified in recent years as the result of a constitutional amendment to reform the judiciary approved by the voters and the cantons on 12 March 2000. Its purpose was to give the Confederation the power to legislate in procedural matters in civil and criminal domains (through amendments to Art. 122 and 123 Const.), though the organization of the judiciary and the administration of justice were to remain, in principle, in the hands of the cantons (Haller 2016: 80). 
In addition, Articles 188 et seq. of the Federal Constitution were modified to permit a complete revision of the Federal Judicial Organization Act intended to introduce a single appeal to the Federal Supreme Court and to regulate-meaning limit-access to this tribunal (Federal Council 2001: 4000). The creation of two new federal courts of first instance, a Federal Criminal Court and a Federal Administrative Court, followed by a Federal Patent Court, was also provided for (Art. 191a Const.).

On 1 January 2007, the new Federal Supreme Court Act (FSCA) of 17 June 2005, which replaced the old Federal Judicial Organization Act of 1943, entered into force. To unify criminal and civil procedures, the Federal Parliament adopted a new Criminal Procedure Code on 5 October 2007 and a new Civil Procedure Code on 19 December 2008. These codes, which entered into force on 1 January 2011, replaced the 26 cantonal codes of criminal procedure and of civil procedure.

As part of the revision of the Swiss Constitution in 1999, a number of new statutes were adopted concerning the two new Federal Courts of First Instance; the Federal Criminal Court Act (of 4 October 2002), later replaced by the Federal Criminal Law Justice Authorities Act of 19 March 2010, in force as of 1 January 2011; the Federal Administrative Court Act of 17 June 2005, in force as of 1 January 2007; and the Federal Patent Court Act of 20 March 2009, in force as of 1 March 2010. We will return briefly below to these different federal courts of first instance. First, however, the Federal Supreme Court, Switzerland's highest court of law, will be presented.

\subsubsection{The Federal Supreme Court}

\subsubsection{The Dual Role of the Federal Supreme Court}

The Federal Supreme Court is 'the supreme judicial authority of the Confederation' (Art. 188 (1) Const.).

The Federal Supreme Court has a dual role. On the one hand, it must ensure that national law is interpreted and applied in a uniform manner, whether these are legislative acts, regulations, or international law (where it plays the role of supreme judge). On the other hand, it needs to guarantee that both federal and cantonal constitutions are respected, including protecting the constitutional rights of individuals (where it plays the role of constitutional judge). It is therefore one and the same court which, as supreme authority, performs the functions of ordinary judge (in civil, criminal, and administrative matters) as well as constitutional judge of the Confederation. As compared with the French judicial system, the 
Swiss Federal Supreme Court combines the roles of the Cour de cassation (the highest court in civil and criminal matters), the Conseil d'Etat (the highest court for administrative justice), and the Conseil constitutionnel (the highest constitutional review authority). In German terms, it combines the roles of the Bundesgerichtshof, Bundesverwaltungsgericht, Bundesfinanzhof, Bundesarbeitsgericht, Bundessozialgericht, as well as that of the Bundesverfassungsgericht.

Consequently, it generally only intervenes as a last resort. As already noted, the control over the application of cantonal law is not only the business of the cantonal courts, but is largely true in the application of federal law-at least at the lower levels - as well. The cantons all have complete, multi-level judicial organizations, but with exceptions for specific areas, the Swiss Confederation has few lower instances. So for the most part, the Federal Supreme Court only acts once the cantonal courts have done their work, and then as a court of appeals against their judgments, whether in civil (Art. 72 et seq. FSCA) or criminal matters (Arts. 78 et seq. FSCA), and in public law (Art. 82 et seq. FSCA). Only in exceptional cases does it judge certain cases as the sole instance, for example, when jurisdictional disputes arise between federal and cantonal authorities, or between cantons (Art. 120 (1) (a) and (b) FSCA).

The law provides for various means of legal redress in bringing a case to the Federal Supreme Court: three ordinary (civil law, criminal law, and public law appeals) and one extraordinary (a subsidiary constitutional appeal). As conditions for admissibility, it also places certain limitations on access, such as setting minimum values in civil or administrative litigation or even restricting access entirely. The FSCA (Art. 83), for example, gives a long list [from a. to $\mathrm{x}$.] of areas where a public law appeal is not admissible, for example.

\subsubsection{The Composition of the Federal Supreme Court and the Appointment of Judges}

By law, the Federal Supreme Court is composed of 35 to 45 ordinary judges (Art. 1 (3), FSCA); the number of deputy judges may not exceed two-thirds of the number of ordinary judges (Art. 1 (4) FSCA). Through a regulation, it is in fact the Federal Assembly which determines the number of judges (Art. 1 (5), FSCA). As of 30 September 2011, this was set at 38 ordinary judges and 19 deputy judges. It is also the Federal Assembly, meaning both houses of Parliament, which elects the federal judges (Arts. 168 (1) and 157 (1) a) Const.).

In practice, Parliament tries to adhere to a proportional representation of the different linguistic regions, the two Christian denominations and, 
above all, the main political parties represented in the Federal Assembly. As a result, federal judges are always associated with a (major) political party (Lienhard et al. 2017: 417-419). When a vacancy occurs, it is the political party of the retiring judge which, in principle, selects and presents replacement candidates to the Judicial Committee of the Federal Assembly. The National Council (lower house) is re-elected every four years; if a significant modification in the equilibrium of the political forces takes place, the new power balance can be taken into account when one or more vacancies appear in the Federal Supreme Court, whence the composition of the latter can be adapted to the new order. Ordinary judges and deputies are elected for a six-year period and can be re-elected (Art. 145 Const. and Art. 9 (1) FSCA).

It is a peculiarity of the Swiss judiciary system that federal judges are elected on a partisan basis, and for a limited time period, by Parliament. Cantons follow suit: some even provide for the popular election of judges, and the terms can vary from one to as many as ten years, depending on the canton. ${ }^{1}$ Such a judicial system is often little understood abroad, given the principle of an independent judiciary. This process is rarely strongly contested in theory and is fairly widely accepted in Switzerland, as it is seen to guarantee to the citizens that judges will represent the existing, and differing, political tendencies or sensitivities in society, at least as represented in Parliament.

According to many authors and even some magistrates, it can give the third power-as with the other two-the democratic legitimacy and the transparency it needs. Added to this argument is the fact that this system is the result of a long tradition and reflects the Swiss conception of democracy. However, the democratic argument loses force with regard to reelection, as judges in most cantons and at the federal level are subject to re-election at regular intervals (Mahon and Schaller 2013a, b). It is theoretically possible that a judge will not be re-elected, and that at the discretion of politicians and without reasons given; this can pose problems in terms of judicial independence. One cannot rule out the potential influence which could be exerted and which could threaten a re-election.

However, while there is no right to be re-elected, in practice, at least thus far, re-election has always been the rule and non-re-election the exception. Judges are virtually never removed for political reasons. The rare cases of a failure to reelect were due to a dysfunction, not politics. Thus, despite the theoretical risk to the independence of the magistrates

${ }^{1}$ The only exception is the canton of Fribourg where judges are elected by the cantonal Parliament, but since 1 January 2008, for an unlimited period. 
which the system suggests, in practice such independence has been relatively well ensured until now. In Switzerland, the risks to an independent judiciary are also linked to the small size of the (cantonal, especially in the first instance) territories in which magistrates exercise their office. The 'cantonalisation' of the judicial system, and in the cantons, its organization into districts, results in an almost complete absence of mobility.

Another peculiarity in recruitment is the absence of initial vocational training for becoming a judge in Switzerland, in contrast to the relatively extensive training which exists, and is required, abroad. However, for federal judgeships, Parliament only selects experienced and eminent jurists from the ranks of the cantonal judges, though they sometimes also choose lawyers or university professors (Lienhard et al. 2017: 418).

Finally, at the cantonal level, cantonal laws sometimes require that judges be domiciled in the canton where they exercise their office.

\subsubsection{The Structure of the Federal Supreme Court}

The headquarters of the Federal Supreme Court are in Lausanne (Art. 4 (1) FSCA), and the work of the court is organized by the domains of law they address. The two divisions which address social law are located in Lucerne (Art. 4 (2) FSCA). Currently, there are two public law divisions (each with six judges), two civil law divisions (one with five, the other with six judges), one criminal law division (five judges), and two social law courts (each with five members). They serve as appeals courts to challenge the judgments of lower cantonal and federal authorities. Other bodies also exist, with their member judges who belong to one of the seven divisions. They include an Appeals Commission, composed of three ordinary judges, which decides in particular about personnel and transparency issues, and two administrative bodies, the Conference of Presidents and the Administrative Commission.

With the exception of the powers-essentially administrative-for which the law requires plenary sessions, the Federal Supreme Court exercises its judicial powers through its divisions, which deliberate alone, unless one of them proposes to derogate from the case law of one or more other divisions, in which case an agreement of that (or those) divisions is necessary (Art. 23 FSCA). The law provides that the divisions are constituted for two years, and as a rule, sit as a three-judge court which is assisted by a law clerk (Haller 2016: 154, 155; Lienhard et al. 2017: 415, 416). If a case concerns a legal question of principle or if a judge so requests, this can be raised to five. A five-judge court is also necessary for appeals against a cantonal act which can be subjected to a referendum, as well as cantonal 
decisions about the admissibility of an initiative or the requirements of a referendum (Art. 18 et seq. FSCA).

In principle, court sessions are open; remarkably, this is also true for the deliberations as well as voting. However, the law provides for the possibility of ordering a closed session (Art. 57 et seq. FSCA) (Haller 2016: 155). In practice, it is possible to choose a simplified procedure, specifically when the decision is to not consider a case (Art. 108 and 109 FSCA), in which judges decide unanimously and by circulating material (Art. 58 FSCA). Open or public deliberations have become rare or very rare.

\subsubsection{The Other Federal Courts}

As noted earlier, as part of the 'reforming the judiciary', and in particular to relieve the Federal Supreme Court, the Federal Assembly created new federal courts of first instance which had not previously existed: the Federal Criminal Court, the Federal Administrative Court, and the Federal Patent Court.

\subsubsection{The Federal Criminal Court}

If the application of the federal criminal law is largely in the hands of the cantonal judicial authorities, in the sense that crimes and offenses are in principle prosecuted and judged by the cantonal prosecuting authorities and courts, there are still certain categories of infractions whose prosecution and adjudication are the responsibility of the federal authorities (namely, the Federal Public Prosecutor and Federal Criminal Court). These include crimes committed against federal authorities or members of foreign states, offenses related to the use of explosives or toxic gases, and crimes and offenses related to forging money. They also include falsifying watermarks, stamps, or official titles used by the Confederation, genocide and crimes against humanity, war crimes, crimes against the state and national defense, crimes which go against the will of the people and the public authorities, and other matters (see the list of offenses listed in Art. 23 and 24 Criminal Procedure Code).

As the first instance, the Federal Criminal Court therefore judges criminal cases which fall within the purview and competence of the Confederation; its decisions can then be appealed to the Federal Supreme Court.

The Federal Criminal Court has its seat in Bellinzona and is composed of 15-35 ordinary judges who are elected by the Federal Assembly. As per a parliamentary order of 13 December 2013, there are currently 16 ordinary judges and three deputies serving on this court. 


\subsubsection{The Federal Administrative Court}

On 1 January 2007, the Federal Administrative Court replaced the 30 or so federal administrative appeals boards that had previously existed. They had been responsible for reviewing, on appeal, the application of federal administrative law in their specific area of competence.

Generally speaking, it is the responsibility of the cantonal administrations to apply federal administrative law. Thus, to take the example of road traffic, cantonal offices are responsible for applying the federal laws regarding car registration. By having the cantons administer federal substantive law, the Confederation had thus been-and is - able to avoid setting up and maintaining a ponderous network of federal offices. In various domains, it has been satisfied with maintaining a relatively small administrative apparatus that in essence supervises the application of federal substantive law by the cantons.

In some areas, however, the federal legislature has chosen to entrust the application of federal administrative law not to the cantons but to a specific federal administrative unit which is created and set up to this end. This is the case, for example, in asylum law, where the decisions about applying the federal laws on asylum are taken by a federal entity, the State Secretariat for Migration (SEM, formerly the Federal Office for Refugees and then the Federal Office for Migration). This is also the case in a number of other, quite disparate domains, including applying customs, nuclear energy, and organ transplantation laws and regulations.

However, in matters of federal administrative law, litigation is organized following a distinction related to competencies. Thus, when federal administrative law is applied in a given field by a cantonal instance, then recourse is first sought in that canton's administrative court. Only then, insofar as a further appeal is admissible, does it go to the Federal Supreme Court. But if federal administrative law is implemented through an administrative authority of the Confederation, then the appeal is to a federal judicial authority, which since 2007, is the Federal Administrative Court. In this new Court, competencies previously scattered among specialized appeals boards have been concentrated in a single appellate authority of first instance.

As long as the law does not preclude the possibility, decisions of the Federal Administrative Court may be appealed to the Federal Supreme Court (Art. 1 (2) FACA). The Federal Administrative Court has its seat in St. Gallen, and is composed of 50-70 judges who are elected by the Federal Assembly. As per a parliamentary order of 17 June 2005, there are currently 65 judges serving on this court. 


\subsubsection{The Federal Patent Court}

The Federal Patent Court Law came into force on 1 March 2010. This Court rules as the first instance of the Confederation in matters of patents, replacing the cantonal courts which previously had competence in this area.

The Federal Patent Court has its seat at the Federal Administrative Court. It is composed of two ordinary judges and 41 deputy judges who must have technical training, meaning that 28 non-permanent judges possess technical training and 13 have legal training. All of them have proven knowledge of patent law, and all are elected by the Federal Assembly.

\subsubsection{Judicial Organization in the Cantons}

The cantons have a great deal of autonomy in terms of judicial organization. With the exception of the federal courts just discussed, all Swiss judicial authorities do indeed proceed from cantonal law. ${ }^{2}$ However, what characterizes this cantonal judiciary organization is its extreme diversity from canton to canton. This is not only a horizontal diversity between cantons but also vertical: one has to distinguish, in each canton, between the civil, criminal, and administrative jurisdictions.

The Swiss Constitution expressly states that the cantons 'are responsible for the organization of the courts and the administration of justice in civil matters' (Art. 122 (2) Const.), and the same is true for jurisdiction in criminal cases (Art. 123 (2) Const.). The Swiss Constitution does not expressly state the same for administrative matters, but jurisdiction here is based similarly on the organizational autonomy of the cantons. The organization of the cantonal judicial authorities includes the questions of territorial jurisdiction, the conditions of appointments and remunerations of the judges, and the finances and the overseeing of the management of courts (Tophinke 2013: 273, 274; Lienhard et al. 2017: 419).

For civil and criminal matters, cantons generally have two authorities at their disposal in their judicial organization. The judicial system is often organized into lower courts, constituted by district or region, depending on the canton, and a single superior instance, usually called the Cantonal Court. In administrative matters, the application of cantonal administrative law is generally the responsibility of the cantonal administration and its departments. Their activities and decisions are usually overseen by the

\footnotetext{
${ }^{2}$ One should also note the exception of military courts and military jurisdiction, both under federal law; they are not addressed further here.
} 
higher cantonal administrative court, which is the final cantonal instance before appealing to the Federal Supreme Court.

\subsection{Constitutional Jurisdiction: An Extensive Review with a Notable Exception}

The so-called in Switzerland 'constitutional jurisdiction' (constitutional justice) is well developed and combines different types of constitutional review (Auer 1983).

Different types of constitutional review are generally identified. It is either centralized in the hands of a (supreme or constitutional) court or decentralized (Cappelleti 1970). It should also be noted that an abstract constitutional review occurs in the absence of a concrete case of application. The Court simply reviews the constitutionality of norms and these will either not come into force or be repealed. By contrast, concrete constitutional review takes place when an individual decision is based on potentially unconstitutional legislation and the court conducts a preliminary review of the legal norm.

Paradoxically, and despite the worldwide enlargement of constitutional justice (Hertig Randall 2010: 221 et seq.), there has been a notable exception in Swiss law with respect to a category of legal norms: federal laws. Indeed, even if they are unconstitutional, federal laws must be applied by courts and authorities. With the exception of this limitation, all state acts (promulgated in the form either of federal statutes, ordinances, and decrees or decisions), whether adopted by federal, cantonal, or municipal authorities, are subject to constitutional review.

To outline the main aspects of constitutional justice in Switzerland, we therefore first examine it from the perspective of legal instruments (Sect. 8.3.1). Then we will examine the peculiarity of having an absence of review of federal laws (Sect. 8.3.2).

\subsubsection{Legal Instruments Subject to Constitutional Review}

As mentioned, other than federal laws (Art. 190 Const.), all legal instruments are subject to constitutional control. Nevertheless, the type of review is not always the same. Two forms of instruments must be distinguished. First, there are 'legal rules' which express binding, abstract, and general norms. Such legal rules can be adopted by the Parliament (statutes 
or ordinances) or by the Executive (ordinances or decrees) at the federal or cantonal level. These legal acts form the legislation. Second, the scope of some legal instruments can be limited to individual and concrete cases, which are then the 'decisions'. Public authorities, such as public administration or the judiciary, can adopt decisions. To look more precisely at consequences on the question of constitutional justice, we will start with the federal regulations. After that, we will consider the cantonal law and finally we will briefly look at decisions.

\subsubsection{Federal Regulations}

Federal legal rules can be adopted in the form of statutes and federal ordinances, which are adopted by the Parliament (statutes and ordinances), the Executive (ordinances), or the department and offices of the federal public administration (ordinances). The sources of review are the Federal Constitution but also international law. However, not all appellants have the possibility of invoking all the provisions of the Federal Constitution, as will be seen.

A concrete constitutional review of federal legal acts is undertaken only when they are applied. This means that when the Federal Council or another federal authority adopts an ordinance contrary to the Constitution, individuals can only challenge the unconstitutional act in the framework of a specific case. In other words, other than in cases of action taken by cantons (see below), there is no 'abstract constitutional review' for federal legal rules, at least not one at the disposal of individuals.

Such a conception of constitutional review was adopted in 1874 in the first Federal Judicial Organization Act, and remained unquestioned. This option was not questioned either when a new Federal Judicial Organization Act was adopted in 1943, or in the latter's replacing FSCA of 2005. However, as already mentioned, there is an exception to this absence of abstract review of federal (non-statutory) acts. Cantons can appeal to the Federal Supreme Court (the formerly so-called public law claim) by claiming that a non-statutory act violates the Federal Constitution, in particular that it violates the division of powers between the Confederation and the cantons, thus encroaching on cantonal competencies. Through this form of appeal can cantons trigger an abstract constitutional review of federal acts by the Federal Court (Art. 189 (2) Const.). In this framework, the Federal Supreme Court does verify the constitutionality (and legality) of federal ordinances. In such cases, the Federal Supreme Court generally shows considerable restraint. If the ordinance is based on legislative dele- 
gation, the Federal Court limits itself to verifying that the author of the ordinance remained within the framework and limits of the delegation. Furthermore, insofar as the law does not authorize the delegate to derogate from the Constitution, the Federal Supreme Court reviews the constitutionality of the ordinance (for the formula generally used by the Federal Supreme Court see, e.g., the Decision of the Federal Supreme Court of 22 December 1978: ATF 104 Ib 412, 420, 421).

Let us add here that the constitutional review is not only concentrated in the hands of the Federal Supreme Court but also decentralized, meaning that any federal or cantonal authority which is responsible for applying federal legislation in a given case must - or at least may-refuse to apply it if they consider it contrary to the Federal Constitution. The question of constitutionality may thus be raised at any stage when applying the legal rules and before any authority. In the end, this question can even be brought to the Federal Supreme Court in principle by ordinary means of appeal (whether in civil, criminal or public law matters).

\subsubsection{Cantonal Law}

The review of cantonal legislation is significantly more extensive than for federal legal rules in two respects. The review can be abstract as well as concrete and, in both cases, is available to individuals. It should be emphasized, however, that the Federal Supreme Court refuses to review-in principle-the cantonal constitutions, on the grounds that these have already been controlled by the Federal Assembly (Art. 172 (2) Const.) (Mahon 2014: 110, 111).

Concerning the sources of the review, it is first of all based on the Federal Constitution and on international law as well. There is also a conformity control with cantonal constitutional law or at least with certain parts of cantonal constitutional law. It must be added that the cantonal norms have to be in conformity with the federal law (see below).

The constitutional review of cantonal norms is decentralized, meaning it applies to all the procedures applying these norms. When applying a cantonal norm in a concrete case, all authorities, administrative or judicial, must - or at least can-refuse its application if they consider it contrary to the Federal Constitution. For example, an administrative court of a canton will thus refuse to apply a tax law if it considers it contrary to the principle of equality (Art. 8 (1) Const.) or refuse to apply a cantonal law on trade if it deems it contrary to economic freedom (Art. 27 Const.). 
The constitutional review of cantonal norms can also be abstract. Indeed, unlike federal acts, a cantonal or municipal act enforced can be appealed for violation of the Constitution outside any cases. In such a hypothesis, the appeal is brought directly before the Federal Court, which judges in principle as the sole and unique body. The review is therefore 'concentrated'. However, the cantons are also free to establish a constitutional court which can review all the laws and ordinances of the canton (Bolkensteyn 2014). Some cantons have done so, including the canton of Jura (Art. 104 Constitution of Jura), the canton of Vaud (Art. 136 Constitution of Vaud), the canton of Graubünden (Art. 55 Constitution of Graubünden), and the canton of Geneva (Art. 124 Constitution of Geneva). The cantons of Nidwalden and Zurich provide such review to a more limited extent (without control of the laws). In such cases, the individuals must first appeal to the cantonal authority and then, on review, take the case to the Federal Supreme Court. An appeal against a cantonal law must be sent to the Federal Supreme Court within 30 days of publishing the cantonal act. Once this period has elapsed, the legal norms can no longer be reviewed in an abstract manner, but it can still be controlled in an application case (concrete control). However, the abstract control does not prevent-with exceptions - the entry into force of the norm.

As cantonal law is applied by the cantons, there is a general right of review in the cantonal judiciary. The remedy must be appealed to in the framework of the application of the norm. Indeed, in concrete cases, when two legal norms are in conflict, the judiciary must determine which one prevails and apply it. Such a power has been derived from the principle that federal laws break cantonal law (Art. 49 Const.) (Mahon 2014: 141-143). Cantons are obliged by federal law to have courts of second instance, meaning cantonal courts or upper courts, and decisions they take can be brought to the Federal Supreme Court if they apply a cantonal norm that violates the Federal Constitution or a constitutional right, by an ordinary means of appeal (appeal in civil matters and appeal in criminal matters will however be rather rarer than appeal in matters of public law insofar as there are none or only few cantonal statutes in these fields). If none of these ordinary appeals are possible, the legislator has created a subsidiary constitutional appeal (Art. 113 FSCA) for which three conditions must been fulfilled: the decision emanates from a cantonal authority of last instance, the appellant invokes a 'violation of constitutional rights', and the appellant must prove a 'legal interest' (Art. 113 to 116 FSCA). 
The means of appeal to review a cantonal legal act by the Federal Supreme Court, without any application, is always the public law remedy (Art. 82b (b) FSCA).

\subsubsection{Decisions Taken by Federal or Cantonal Authorities}

Administrative authorities and the judiciary make decisions in which legal rules are applied. Their common feature is that they concern an individual and specific case, and all levels - federal, cantonal, and local authoritiescan make such decisions. They are the last category to be considered under this section.

Such legal instruments are subject to reviews of their constitutionality regardless of the legal norm on which they are based. It is alleged that the decision itself is violating the Constitution. In other words, it is how the law is applied which is - supposedly-contrary to the Constitution and not the legal norm on which the decision is based. Unlike the decision, the legal norm can be entirely in accordance with the Constitution.

The remedies for the constitutionality review against such acts are those applied in general. As far as the Federal Supreme Court is concerned, as the last instance, the remedies (civil matters, criminal matters, public law matters or subsidiary constitutional appeal) depend on the subject. Appeals are directed either against the cantonal court, the Federal Administrative Court, the Federal Criminal Court or another federal authority (Haller 2016: 153). Nevertheless, individual decisions taken by the Federal Assembly ( e.g. concerning the validity of a popular initiative) are excluded from the constitutional review despite the fact that it creates a conflict with the guarantee of access to the courts guaranteed by the Swiss constitution in Article 29 (Haller 2016: 263).

\subsubsection{A Breach of the Rule of Law: The Case of Federal Laws (and of International Law)}

Article 190 of the Federal Constitution provides that 'the Federal Supreme Court and the other judicial authorities must apply the federal acts and international law'. Known as the 'immunity clause' of federal laws, the constitutional provision limits the constitutional review of legal norms in Switzerland. It implies that federal statutes adopted by the Federal Assembly, having found the endorsement-explicit or tacit-of the Swiss people, have to be applied even when they have no constitutional basis or are in conflict with the Federal Constitution. That being said, the Federal 
Assembly must respect the Federal Constitution when adopting laws. To understand better the scope of such a limitation, we will briefly evoke the reasons behind it and question this breach in the Swiss constitutional justice. We will thereafter describe the extent of the notion of 'immunity' and will finish by presenting its mitigated effect due to international law.

\subsubsection{Reasons and Questions on the Breach}

This rule also applies to international laws. In this case, it is motivated by the concern of ensuring the international credibility of Switzerland. To put it another way, once an international law has been validly adopted, the binding rules resulting from international obligations must be respected.

The reason for limiting the constitutional review in Article 190 Const. is founded in concepts of separation of powers and direct democracy. The constituent power of 1874 made these two principles prevail over the idea of complete judicial control of legal norms. In short, the idea was that a federal law should rarely be contrary to the Constitution. Most often, it is the opinion of the sense of the Constitution which varies according to interpretations. Finally, there was also no reason to prefer the interpretation of a court to that of Parliament. Such a vision of the constituent power in 1848 occurs at a time where there were very few legislative powers and therefore federal laws.

Nevertheless, the immunity of federal laws has always been debated, and the question of whether it (still) has a raison d'être remains controversial today. While many legal scholars advocate to enlarge the constitutional review to federal laws, the political authorities have always been opposed to it, at least in their majority. Two motions in 1923 and 1924 and a popular initiative in 1939 were rejected. At the time of the total revision of the Swiss Constitution, the Federal Council proposed-in the project on the 'reform of the justice system' (Federal Council 1997: 652) — to abrogate, at least partially, such a rule of immunity of the federal laws but the Federal Assembly did not agree. The Federal Council once again proposed a partial lifting of the immunity of federal laws in the framework of the reform of financial equalization and division of powers between the Confederation and the cantons (the so-called "RPT reform" (for "Réforme de la péréquation et de la répartition des tâches"), Federal Council 2002: 2155). The cantons, and only they, would have had the opportunity to challenge federal laws affecting their sphere of jurisdiction, but this proposal too was rejected by Parliament. Two more recent parliamentary interventions proposing the repeal of Article 190 Const. have also suffered a similar fate (Report of the National Council's Legal Affairs Committee 2011: 6707-6724; Federal Council 2011: 6995-7000). 
This notable exception inside the constitutional justice seems thus deeply entrenched in the Swiss constitutional beliefs and shows a certain contradiction with the idea of constitutional state, in which all legal norms must absolutely be adopted in conformity with the constitution and be reviewed by an independent court. It is now appropriate to consider more specifically the scope of this concept of 'immunity'.

\subsubsection{The Scope of the Notion of 'Immunized' Legal Norms}

As stated in Article 190 Const., it is federal laws and international law which are immunized. Considering federal laws, this applies to both ordinary and urgent laws (Art. 165 Const.; Mahon 2014: 275). Other legislative instruments are not open to review by the Federal Supreme Court.

Indeed, as already mentioned, the cantonal constitutions are also immune against the (federal) constitutional review. Such an interpretation has been developed in the case law of the Federal Supreme Court, which often argued that cantonal constitutions are guaranteed by the Federal Assembly (Art. 51 (2) Const.). This Supreme Court jurisprudence is often criticized by legal scholars (Grisel 1996; Töndury 2004). They consider that the review exercised by the Federal Assembly is too summary to bind the courts. The Federal Court has remained unmoved by this critique and continues to refrain from checking whether cantonal constitutions are in conformity with federal law. However, it must be noted that the Court has exceptionally agreed to check the conformity of the cantonal constitution with the rules of federal law that were adopted after the granting of the Federal Parliament's guarantee. In such a case, it is not likely to disavow the Federal Assembly (see Decision of the Federal Supreme Court of 18 Mai 2004: ATF 131 I 126, 130, where the Federal Court notes, despite the almost unanimous criticism among Swiss legal scholars, that there is no need to change the case law).

In addition, when a legal norm inferior (e.g. an ordinance or a cantonal decree) to a federal law, in the hierarchy of norms, repeats or applies an unconstitutional legal rule found in an immunized act (e.g. federal law), the former is also covered by this immunity clause. It is therefore an indirect effect - a reaction, in a way - of this immunity. Indeed, the Federal Court has considered that such a norm is not controllable, because here the review would relate, indirectly, to the immunized act and would come up against the immunity clause. Such is the case of a federal ordinance, adopted by the Federal Council or the Assembly, which repeats or executes the solution chosen by the federal legislators (Mahon 2014: 329, 330; Haller 2016: 261). 


\subsubsection{The Mitigated Effects of the 'Immunity Clause' and the Relationship Between National and International Law}

If the immunity clause of federal laws is not ready to be questioned by the political authorities, it has been, however, subject to various attenuations.

The first of these temperaments is that the enforcement authority can, while applying the law, criticize it and even invite the legislator to modify the provision in question. In other words, to use the German adage often used to illustrate this aspect, Article 190 provides an Anwendungsgebot but not a Prüfungsverbot - an application directive but not a prohibition on scrutinizing it (see Decision of the Federal Supreme Court of 11 December 1996: ATF 123 II 9).

Another form of mitigation of the rule of immunity of federal laws is related to the principle called interpretation in conformity with the Constitution'. Concretely, when a law is open to more than one interpretation, the implementing authority gives the preference to the one compatible with the Constitution. Such a margin of discretion can only go so far in an attempt to give a norm a constitutional content, as the authority cannot deviate from the clear text of a legal norm (see Decision of the Federal Supreme Court of 12 July 1993: ATF 119 Ia 241).

Third temperament to the rule of immunity is the fact that a new constitutional provision prevails, if it is sufficiently precise, over an earlier statute. This is logical, as far as prevails the subsequent decision of an organ endowed with a greater legitimacy (the constituent) than that of the legislator.

To conclude on the question of the immunity rule, it must be noted that Article. 190 Const. does not answer the question of which rule prevails in the event of a conflict between a provision of a federal-immunized-law and that of an international treaty - which benefits from the immunity clause provided in Article 190 Const. as well. On this question, Article 5 (4) Const. entrenches the principle of the primacy of international law. It means that a provision of an international treaty prevails on a domestic law provision. This rule must be underlined. Indeed, the Federal Supreme Court has admitted, in some cases, to review federal laws in light of the international law of the European Convention of Human Rights or the UN Covenants (Hertig Randall 2010: 248 et seq.). Such a test is known as the 'control of conventionality', skirting around the limit of the constitutional review of Swiss laws.

\section{REFERENCES}

Auer, A. (1983). La juridiction constitutionnelle en Suisse. Basel: Helbing \& Lichtenhahn. Bolkensteyn, A. (2014). Le contrôle des normes, spécialement par les cours constitutionnelles cantonales. Bern: Staempfli. 
Cappelletti, M. (1970). Judicial review in comparative perspective. California Law Review, 58, 1017-1053.

Federal Council. (1997). Message du Conseil fédéral du 20 novembre 1996 relatif à la nouvelle constitution fédérale. Fenille fédérale I, 1-653.

Federal Council. (2001). Message du Conseil fédéral du 28 février 2001 concernant la révision totale de l'organisation judiciaire fédérale. Fenille fédérale, 4000-4280.

Federal Council. (2002). Message du Conseil fédéral du 14 novembre 2001 concernant la Réforme de la péréquation financière et de la répartition des tâches entre la Confédération et les cantons (RPT). Fenille fédérale, 2155-2414.

Federal Council. (2011). Avis du Conseil fédéral du 30 Septembre 2011 sur la Juridiction constitutionnelle. Fenille fédérale, 6995-7000.

Grisel, E. (1996). La garantie des constitutions cantonales: une procédure politique ou une procédure judiciaire? In J.-M. Rapp \& M. Jacquard (Eds.), Le droit en action. Lausanne: Faculté de droit.

Haller, W. (2016). The Swiss constitution in a comparative context. Dike: Zurich/ St Gall.

Hertig Randall, M. (2010). L'internationalisation de la juridiction constitutionnelle: défis et perspectives. Revue de droit suisse, 129(2), 221-380.

Lienhard, A., Kettiger, D., Bühler, J., Mérillat, L., \& Winkler, D. (2017). The federal supreme court of Switzerland: Judicial balancing of federalism without judicial review. In N. Aroney \& J. Kincaid (Eds.), Courts in federal countries: Federalists or unitarists? (pp. 404-430). Toronto: University of Toronto Press.

Mahon, P. (2014). Droit Constitutionnel. Institutions, juridiction constitutionnelle et procédure (Vol. 1). Bâle: Helbing Lichtenhahn.

Mahon, P., \& Schaller, R. (2013a). L'élection des juges entre tradition démocratique et exigences de l'Etat de droit. Parlament-Parlement-Parlamento, 2, $1-17$.

Mahon, P., \& Schaller, R. (2013b). Le système de réélection des juges: évidence démocratique ou épée de Damoclès? Justice-Justiz-Giustizia, 1, 1-13.

National Council's Legal Affairs Committee. (2011). Parliamentary initiatives, constitutional jurisdiction: Making the constitution workable for the law enforcement authorities. Fenille fédérale, 6707-6724.

Töndury, A. (2004). Bundesstaatliche Einheit und kantonale Demokratie - Die Gewährleistung der Kantonsverfassungen nach Art. 51 BV. Zürich: Zürcher Studien zum öffentlichen Recht Bd. 160.

Tophinke, E. (2013). Tribunaux et jurisprudence. In A. Ladner, J.-L. Chappelet, Y. Emery, P. Knoepfel, L. Mader, N. Soguel, \& F. Varone (Eds.), Manuel d'administration publique Suisse (pp. 267-282). Lausanne: Presses polytechniques et universitaires romandes. 
Open Access This chapter is licensed under the terms of the Creative Commons Attribution 4.0 International License (http://creativecommons.org/licenses/ by $/ 4.0 /$ ), which permits use, sharing, adaptation, distribution and reproduction in any medium or format, as long as you give appropriate credit to the original author(s) and the source, provide a link to the Creative Commons license and indicate if changes were made.

The images or other third party material in this chapter are included in the chapter's Creative Commons license, unless indicated otherwise in a credit line to the material. If material is not included in the chapter's Creative Commons license and your intended use is not permitted by statutory regulation or exceeds the permitted use, you will need to obtain permission directly from the copyright holder.

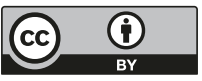

